\title{
A Novel Antimycin-like Compound, JBIR-06, from Streptomyces sp. ML55
}

\author{
Jun-ya Ueda, Aya Nagai, Miho Izumikawa, Shuhei Chijiwa, Motoki Takagi, \\ Kazuo Shin-ya
}

Received: February 15, 2008 / Accepted: March 19, 2008

(C) Japan Antibiotics Research Association

\begin{abstract}
A novel compound of antimycin family, JBIR-06 (1), was isolated from Streptomyces sp. ML55. The structure of $\mathbf{1}$ was established as a twelve-membered macrocyclic skeleton with a 3-(formylamino)-2hydroxybenzamide based on the spectroscopic data. Compound 1 inhibited the expression of GRP78 induced by 2-deoxyglucose at the $\mathrm{IC}_{50}$ value of $250 \mathrm{nM}$.
\end{abstract}

Keywords antimycin, JBIR-06, molecular chaperone, GRP78, Streptomyces sp.

GRP78, which is well-known as a molecular chaperone in the endoplasmic reticulum (ER), also plays an important role as a survival factor in solid tumors, due to its acquisition of a resistant mechanism against both chemotherapy and hypoglycemic stress [1]. Thus, specific down-regulators of GRP78 transcription can reasonably be expected to become promising drugs in cancer chemotherapy [2]. In the course of our screening program for down-regulators of GRP78/Bip molecular chaperone expression, we isolated versipelostatin [3], prunustatin A [4, 5], JBIR-04, -05 [6] and SW-163A [6]. Further screening resulted in the isolation of a novel inhibitor of GRP78 expression, designated as JBIR-06 (1, Fig. 1), a new member of antimycin [7] family from mycelium of Streptomyces sp. ML55 [8]. In this paper, we report

K. Shin-ya (Corresponding author): Biological Information Research Center (BIRC), National Institute of Advanced Industrial Science and Technology (AIST), 2-42 Aomi, Koto-ku, Tokyo 135-0064, Japan, E-mail: k-shinya@aist.go.jp the isolation, structure elucidation, and brief biological activities of $\mathbf{1}$.

The Streptomyces sp. ML55 was cultured at $27^{\circ} \mathrm{C}$ for 5 days in 500-ml Erlenmeyer flasks containing a medium consisting of $2.0 \%$ glycerin (Nacalai Tesque), $1.0 \%$ molasses (Dai-Nippon Meiji Sugar), $0.5 \%$ casein (KANTO CHEMICAL), $0.1 \%$ polypepton (NIHON PHARMACEUTICAL), $\quad 0.4 \% \quad \mathrm{CaCO}_{3} \quad$ (KOZAKAI PHARMACEUTICAL) (pH 7.2 before sterilization). The mycelium from the culture broth (2.0 liters) was extracted with $\mathrm{Me}_{2} \mathrm{CO}(400 \mathrm{ml})$. After concentrated in vacuo, the residue was extracted with EtOAc for two times. The organic layer was dried over $\mathrm{Na}_{2} \mathrm{SO}_{4}$, and concentrated in vacuo. The dried residue was applied to normal-phase MPLC (Purif-Pack SI-60, Moritex) and developed with a

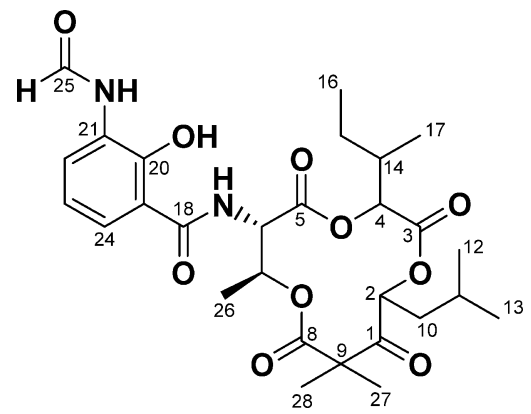

Fig. 1 Structure of JBIR-06 (1).

M. Takagi (Corresponding author), J. Ueda, A. Nagai, M. Izumikawa, S. Chijiwa: Japan Biological Information Research Center (JBIRC), Japan Biological Informatics Consortium (JBIC), 2-42 Aomi, Koto-ku, Tokyo 135-0064, Japan,

E-mail: motoki-takagi@aist.go.jp 
Table 1 Physico-chemical properties of JBIR-06 (1)

\begin{tabular}{ll}
\hline Appearance & Light brown amorphous solid \\
Melting point ${ }^{\mathrm{a}}$ & $90.0 \sim 97.5^{\circ} \mathrm{C}$ \\
{$[\alpha]_{D}^{22}(\mathrm{MeOH})^{\mathrm{b}}$} & $-30.0^{\circ}(\mathrm{c} 0.04)$ \\
Molecular formula & $\mathrm{C}_{28} \mathrm{H}_{38} \mathrm{~N}_{2} \mathrm{O}_{10}$ \\
HR-ESI-MS $(\mathrm{m} / \mathrm{z})^{\mathrm{c}}$ & found: $563.2609[\mathrm{M}+\mathrm{H}]^{+}$ \\
& calcd: 563.2605 for $\mathrm{C}_{28} \mathrm{H}_{39} \mathrm{~N}_{2} \mathrm{O}_{10}$ \\
UV $\lambda_{\max }(\mathrm{MeOH}) \mathrm{nm}(\varepsilon)^{d}$ & $225(22700), 334(3760)$ \\
IR $v_{\max }\left(\mathrm{CHCl}_{3}\right) \mathrm{cm}^{-1 f}$ & $1738,1644,1527,1281,1211$
\end{tabular}

${ }^{a}$ Melting point was determined with a Yanagimoto micro melting point apparatus. ${ }^{b}$ Optical rotation was operated on a HORIBA SEPA-300 polarimeter. ${ }^{\circ} \mathrm{HR}$-ESI-MS data were recorded on a Waters LCT-Premier XE. ${ }^{d}$ UV spectrum was measured on a HITACHI U-3200

spectrophotometer. ${ }^{\dagger}$ IR spectrum was obtained using a HORIBA FT-720 spectrophotometer.

hexane - EtOAc linear gradient system $(0 \sim 100 \%$ EtOAc), and the peak detection was carried out by UV absorption at $254 \mathrm{~nm}$. The $60 \sim 75 \%$ EtOAc eluate was subjected to preparative reversed-phase HPLC (mobile phase: 65\% $\mathrm{MeCN}-\mathrm{H}_{2} \mathrm{O}$; column: Senshu Pak PEGASIL ODS 20 i.d. $\times 250 \mathrm{~mm}$; detector: Waters 2996 photodiode array detector and Waters 3100 mass detector) to yield $\mathbf{1}(1.5 \mathrm{mg}$; Rt, 42.1 minutes).

The physico-chemical properties of $\mathbf{1}$ are summarized in Table 1. Compound 1 was obtained as light brown amorphous solid (MP 90.0 97. $5^{\circ} \mathrm{C}$ ) and its molecular formula was determined to be $\mathrm{C}_{28} \mathrm{H}_{38} \mathrm{~N}_{2} \mathrm{O}_{10}$ by HR-ESIMS. The IR spectrum showed absorbance for esters and amides $\left(1738,1644,1211 \mathrm{~cm}^{-1}\right)$. The direct connectivity between protons and carbons was established by the HSQC spectrum and the ${ }^{13} \mathrm{C}$ - and ${ }^{1} \mathrm{H}-\mathrm{NMR}$ spectral data for $\mathbf{1}$ are shown in Table 2. The DQF-COSY and HMBC spectra established four partial structures (Fig. 2).

The sequence from an oxymethine proton $2-\mathrm{H}\left(\delta_{\mathrm{H}} 5.61\right)$ to $11-\mathrm{H}\left(\delta_{\mathrm{H}} 1.62\right)$, which in turn coupled to two methyl protons $12-\mathrm{H}\left(\delta_{\mathrm{H}} 0.95\right)$ and $13-\mathrm{H}\left(\delta_{\mathrm{H}} 0.941\right)$, through $10-\mathrm{H}$ $\left(\delta_{\mathrm{H}} 1.84,1.72\right)$ in the COSY spectrum established a 3 methylbutyl moiety. Two singlet methyl protons $27-\mathrm{H}\left(\delta_{\mathrm{H}}\right.$ $1.36)$ and $28-\mathrm{H}\left(\delta_{\mathrm{H}} 1.17\right)$ were each long-range coupled to an ester carbonyl carbon $\mathrm{C}-8\left(\delta_{\mathrm{C}} 171.9\right)$, a quaternary carbon C-9 $\left(\delta_{\mathrm{C}} 53.5\right)$ and a ketone carbonyl carbon C-1 $\left(\delta_{\mathrm{C}} 204.8\right)$, which in turn long-range coupled to $2-\mathrm{H}$ and $10-\mathrm{H}$. These HMBC correlations indicated the successive connectivity of C-2, C-1, C-9 and C-8 as shown in Fig. 2. Thus, a 2,2,6-trimethyl-3-oxo-4-oxyheptanoate moiety was elucidated as a partial structure of $\mathbf{1}$ as shown in Fig. 2.

The proton sequence between the aromatic protons $22-\mathrm{H}$ $\left(\delta_{\mathrm{H}} 8.58\right), 23-\mathrm{H}\left(\delta_{\mathrm{H}} 6.97\right)$ and $24-\mathrm{H}\left(\delta_{\mathrm{H}} 7.33\right)$ indicated the presence of a $1,2,3$-trisubstituted benzene ring moiety.
Table $2{ }^{1} \mathrm{H}-(600 \mathrm{MHz})$ and ${ }^{13} \mathrm{C}-\mathrm{NMR}(150 \mathrm{MHz})$ data for 1

\begin{tabular}{|c|c|c|}
\hline & $\delta_{\mathrm{H}}$ & $\delta_{\mathrm{C}}$ \\
\hline 1 & & 204.8 \\
\hline 2 & $5.61(\mathrm{dd}, 7.6,4.7)$ & 77.8 \\
\hline 3 & & 168.9 \\
\hline 4 & $5.268(d, 6.2)$ & 77.4 \\
\hline 5 & & 167.8 \\
\hline 6 & $5.270(\mathrm{dd}, 8.5,3.2)$ & 55.3 \\
\hline 7 & $5.68(q d, 6.5,3.2)$ & 72.6 \\
\hline 8 & & 171.9 \\
\hline 9 & & 53.5 \\
\hline \multirow[t]{2}{*}{10} & $1.84(\mathrm{ddd}, 14.5,8.7,4.7)$ & 43.0 \\
\hline & 1.72 (ddd, $14.4,7.6,5.6)$ & \\
\hline 11 & $1.62(\mathrm{~m})$ & 24.59 \\
\hline 12 & $0.95(d, 6.5)$ & 21.9 \\
\hline 13 & $0.941(d, 6.5)$ & 22.7 \\
\hline 14 & $2.04(\mathrm{~m})$ & 37.1 \\
\hline \multirow[t]{2}{*}{15} & $1.57(\mathrm{~m})$ & 24.56 \\
\hline & $1.31(\mathrm{~m})$ & \\
\hline 16 & $1.00(d, 6.8)$ & 11.1 \\
\hline 17 & $0.939(t, 7.3)$ & 15.1 \\
\hline 18 & & 170.2 \\
\hline 19 & & 112.7 \\
\hline 20 & & 150.5 \\
\hline 21 & & 127.4 \\
\hline 22 & $8.58(\mathrm{dd}, 7.9,1.0)$ & 124.9 \\
\hline 23 & $6.97(t, 8.1)$ & 119.1 \\
\hline 24 & $7.33(\mathrm{dd}, 8.1,1.0)$ & 120.2 \\
\hline 25 & 8.52 (br s) & 159.0 \\
\hline 26 & $1.37(d, 6.5)$ & 15.9 \\
\hline 27 & $1.36(\mathrm{~s})$ & 23.2 \\
\hline 28 & 1.17 (s) & 20.6 \\
\hline 6-NH & $7.06(\mathrm{brd}, 8.5)$ & \\
\hline $20-\mathrm{OH}$ & $12.58(\mathrm{br} \mathrm{s})$ & \\
\hline 21-NH & 7.92 (br s) & \\
\hline
\end{tabular}

NMR spectra were recorded on a Varian NMR System 600 NB CL. The Sample was dissolved in $\mathrm{CDCl}_{3}$, and the solvent peak was used as an internal standard ( $\delta_{\mathrm{H}} 7.24$ and $\left.\delta_{\mathrm{c}} 77.0\right)$.

An amide proton $21-\mathrm{NH}\left(\delta_{\mathrm{H}} 7.92\right)$ was coupled to an aldehyde proton $25-\mathrm{H}\left(\delta_{\mathrm{H}} 8.52\right)$, which was considered to connect directly with this amide nitrogen atom from its ${ }^{13} \mathrm{C}$ chemical shift $\left(\delta_{\mathrm{C}} 159.0\right)$. The aldehyde proton and the aromatic proton $23-\mathrm{H}$ were long-range coupled to an aromatic quaternary carbon $\mathrm{C}-21\left(\delta_{\mathrm{C}} 127.4\right)$. These results suggested that the formamide group was substituted at the position of $\mathrm{C}-21$. The aromatic proton $24-\mathrm{H}$ was long-range coupled to a carbonyl carbon $\mathrm{C}-18\left(\delta_{\mathrm{C}} 170.2\right)$ at the peri position, which indicated that this carbonyl carbon was substituted at C-19 $\left(\delta_{\mathrm{C}} 112.7\right)$. The aromatic protons $22-\mathrm{H}$ 


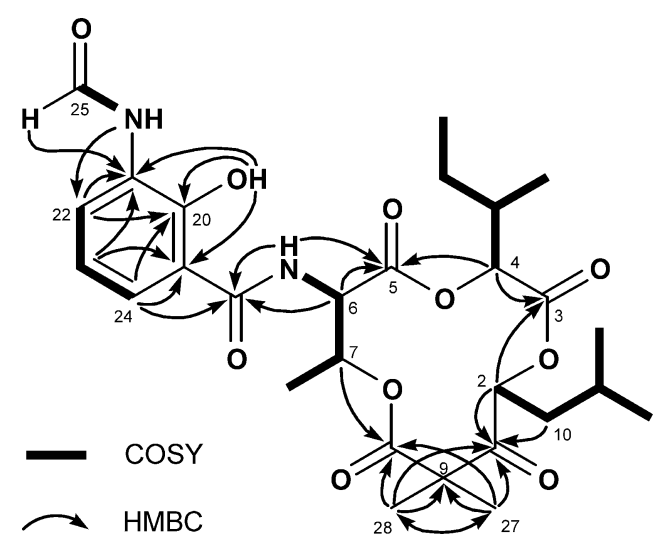

Fig. 2 Key correlations in $2 \mathrm{D}$ NMR $\left({ }^{1} \mathrm{H}-{ }^{1} \mathrm{H}\right.$ COSY and $\mathrm{HMBC})$.

and $24-\mathrm{H}$ in addition to a phenolic hydroxy proton $20-\mathrm{OH}$ $\left(\delta_{\mathrm{H}} 12.58\right)$ were long-range coupled to an aromatic carbon $\mathrm{C}-20\left(\delta_{\mathrm{C}} 150.5\right)$. By taking into consideration these ${ }^{13} \mathrm{C}$ chemical shifts of aromatic carbons, an oxygen atom should be substituted at the $\mathrm{C}-20$ position. Other ${ }^{1} \mathrm{H}-{ }^{13} \mathrm{C}$ long-range couplings as shown in the Fig. 2 and the UV spectrum of 1 also suggested the existence of the 3(formylamino)-2-hydroxybenzoyl moiety, which is the same chromophore as those of the antimycin related compounds [4 7].

The sequence from an amide proton $6-\mathrm{NH}\left(\delta_{\mathrm{H}} 7.06\right)$ to a methyl proton $26-\mathrm{H}\left(\delta_{\mathrm{H}} 1.37\right)$ through an $\alpha$-methine proton $6-\mathrm{H}\left(\delta_{\mathrm{H}} 5.270, \delta_{\mathrm{C}} 55.3\right)$ and an oxymethine proton 7-H $\left(\delta_{\mathrm{H}} 5.68\right)$ was observed in the DQF-COSY spectrum of 1 . In addition to these correlations, the long-range couplings from the methine proton $6-\mathrm{H}$ and the amide proton 6-NH to a carbonyl carbon $\mathrm{C}-5\left(\delta_{\mathrm{C}} 167.8\right)$ and the amide carbonyl carbon $\mathrm{C}-18$ were observed. These results established a threonine residue and its connectivity with the chromophore moiety.

The remaining substructure was also determined by the interpretation of ${ }^{1} \mathrm{H}-{ }^{1} \mathrm{H}$ spin couplings and ${ }^{1} \mathrm{H}-{ }^{13} \mathrm{C}$ long-range couplings as follows. The long-range coupling between an oxymethine proton $4-\mathrm{H}\left(\delta_{\mathrm{H}} 5.268\right)$ and an ester carbonyl carbon $\mathrm{C}-3\left(\delta_{\mathrm{C}} 168.9\right)$, along with the sequence from $4-\mathrm{H}$ to $16-\mathrm{H}\left(\delta_{\mathrm{H}} 1.00\right)$ through $14-\mathrm{H}\left(\delta_{\mathrm{H}} 2.04\right)$, which was additionally coupled to a methyl proton $17-\mathrm{H}$ $\left(\delta_{\mathrm{H}} 0.939\right)$, and $15-\mathrm{H}\left(\delta_{\mathrm{H}} 1.57,1.31\right)$ observed in the DQF-COSY spectrum of 1, established a 3-methyl-2oxypentanoate moiety as shown in Fig. 2. The connectivity of these partial structures were elucidated by the long-range couplings between $2-\mathrm{H}$ and $\mathrm{C}-3,4-\mathrm{H}$ and $\mathrm{C}-5,7-\mathrm{H}$ and $\mathrm{C}-8$, respectively. In this manner, the planar structure of $\mathbf{1}$ was determined as shown in Fig. 1. Although nine-, fifteen-, and eighteen-membered macrocyclic analogs, such as antimycin A, neoantimycin and respirantin, respectively, were frequently isolated [4 7, 9 11], 1 is the first example which consists of a twelve-membered macrocyclic skeleton attached with a 3-(formylamino)-2hydroxybenzoyl in amide linkage.

The absolute configuration of the threonine moiety of 1 was determined as follows. Compound $\mathbf{1}(0.12 \mathrm{mg})$ was hydrolyzed with $3 \mathrm{~N} \mathrm{NaOH}(0.2 \mathrm{ml})$ for 10 minutes at $95^{\circ} \mathrm{C}$. Then, $6 \mathrm{~N} \mathrm{HCl}$ was added to this reaction mixture to adjust the $\mathrm{pH}$ to $2 \sim 3$ followed by the extraction with EtOAc. The aqueous layer was further subjected to acid hydrolysis $(6 \mathrm{~N} \mathrm{HCl}, 0.5 \mathrm{ml})$ for 12 hours at $120^{\circ} \mathrm{C}$ to obtain the threonine residue. After acid hydrolysis, the reaction solution was adjusted to neutral and evaporated in vacuo. To determine the absolute configuration of the threonine residue, Marfey's method was adopted [12]. The residue was dissolved in $0.1 \mathrm{M} \mathrm{NaHCO}_{3}$ aq $(0.1 \mathrm{ml})$ and successively $10 \mathrm{mM} \quad N^{\alpha}$-(5-fluoro-2,4-dinitrophenyl)-Lalaninamide (FDAA) in $\mathrm{Me}_{2} \mathrm{CO}(0.1 \mathrm{ml})$ was added. The mixture was kept at $70^{\circ} \mathrm{C}$ for 10 minutes with frequent shaking. After workup with the addition of $0.2 \mathrm{~N} \mathrm{HCl}$, the filtered reaction mixture was subjected to Waters UPLC ${ }^{\mathbb{B}}$ system (Acquity $\mathrm{UPLC}^{\circledR} \mathrm{BEH} \mathrm{C}_{18} 1.7 \mu \mathrm{m}, 2.1 \times 50 \mathrm{~mm}$, $10 \% \mathrm{MeCN}-\mathrm{H}_{2} \mathrm{O}$ with $0.1 \%$ formic acid). The standard D- and L-threonine and D,L-allo-threonine were reacted with FDAA in the same manner as described above. The threonine residue obtained from the lysate was determined to be L-threonine (Rt: 10.7 minutes; L-Thr, 10.5 minutes; D-Thr, 29.1 minutes; L-allo-Thr, 11.3 minutes; D-allo-Thr, 17.2 minutes).

The human fibrosarcoma cell line HT1080 cells which were transformed with the luciferase reporter gene under the regulation of the GRP78 promoter, produced luciferase by four fold greater quantity than did the control when treated with $10 \mathrm{mM}$ of 2-deoxyglucose [13]. In this evaluation system, 1 reduced the expression of the reporter gene with the $\mathrm{IC}_{50}$ value of $262 \mathrm{nM}$. In the same manner, the structurally related compounds prunustatin A and SW$163 \mathrm{~A}$ exhibited inhibitory activities in this assay with $\mathrm{IC}_{50}$ values of $1.9 \mathrm{nM}$ and $9.1 \mathrm{nM}$, respectively. Since antirespiratory agents such as antimycin, alloaureothin [14], rotenone, oligomycin and verrucosidin $[15,16]$ show the inhibitory activities against GRP78 expression, we briefly evaluated reducing activities of $\mathbf{1}$, prunustatin A and SW-163A in DPPH radical scavenging assay system [17]. In this assay, 1, prunustatin A and SW-163A reduced the DPPH radical by $56.2,54.5$ and $54.5 \%$, respectively, at the concentration of $20 \mu \mathrm{M}$. Since antirespiratory activities of these compounds are almost the same and the inhibitory activities against GRP78 expression of $\mathbf{1}$ was 130 
times less than that of prunustatin A, the size of ring system is considered to play a significant role to exhibit the inhibitory effects against GRP78 expression induced by the treatment of 2-deoxyglucose. These results suggested that antirespiratory effect is not the active center of these compounds. Although the action mechanism for the inhibitory effects against GRP78 expression of versipelostatin was investigated detailed [13], its target is still unknown. Clarifying the target of these compounds is expected to discover the novel and undiscovered pathway of GRP78 expression.

Acknowledgement This work was supported by the grant from the New Energy and Industrial Technology Development Organization (NEDO) of Japan.

\section{References}

1. Katschinski DM, Jacobson EL, Wiedemann GJ, Robins HI. Modulation of VP-16 cytotoxicity by carboplatin and $41.8^{\circ} \mathrm{C}$ hyperthermia. J Cancer Res Clin Oncol 127: 425-435 (2001)

2. Imaizumi K, Miyoshi K, Katayama T, Yoneda T, Taniguchi M, Kubo T, Tohyama M. The unfolded protein response and Alzheimer's disease. Biochem Biophys Acta 1536: 85-96 (2001)

3. Park HR, Furihata K, Hayakawa Y, Shin-ya K. Versipelostatin, a novel GRP/Bip molecular chaperone down-regulator of microbial origin. Tetrahedron Lett 43: 6941-6945 (2002)

4. Umeda Y, Chijiwa S, Furihata K, Furihata K, Sakuda S, Nagasawa H, Watanabe H, Shin-ya K. Prunustatin A, a novel GRP78 molecular chaperone down-regulator isolated form Streptomyces violaceoniger. J Antibiot 58: 206-209 (2005)

5. Umeda Y, Furihata K, Sakuda S, Nagasawa H, Ishigami K, Watanabe H, Izumikawa M, Takagi M, Doi T, Nakao Y, Shin-ya K. Absolute structure of prunustatin A, a novel GRP78 molecular chaperone down-regulator. Org Lett 9: 4239-4242 (2007)

6. Izumikawa M, Ueda J, Chijiwa S, Takagi M, Shin-ya K. Novel GRP78 molecular chaperone expression downregulators JBIR-04 and -05 isolated from Streptomyces violaceoniger. J Antibiot 60: 640-644 (2007)
7. Watanabe K, Tanaka T, Fukuhara K, Miyairi N, Yonehara $\mathrm{H}$, Umezawa H. Blastmycin, a new antibiotic from Streptomyces sp. J Antibiot 10: 39-45 (1957)

8. Ueda J, Togashi T, Matsukura S, Nagai A, Nakashima T, Komaki H, Anzai K, Harayama S, Doi T, Takahashi T, Natsume T, Kisu Y, Goshima N, Nomura N, Takagi M, Shinya K. A novel nuclear export inhibitor JBIR-02, a new piericidin discovered from Streptomyces sp. ML55. J Antibiot 60: 459-462 (2007)

9. Urushibata I, Isogai A, Matsumoto S, Suzuki A. Respirantin, a novel insecticidal cyclodepsipeptide from Streptomyces. J Antibiot 46: 701-703 (1993)

10. Caglioti L, Misiti D, Mondelli R, Selva A, Arcamone F, Cassinelli G. The structure of neomycin. Tetrahedron 25: 2193-2221 (1969)

11. Takahashi K, Tsuda E, Kurosawa K. SW-163A and B, novel immunosuppressants produced by Streptomyces sp. J Antibiot 54: 867-873 (2001)

12. Adamson JG, Hoang T, Crivici A, Lajoie GA. Use of Marfey's reagent to quantitate racemization upon anchoring of amino acids to solid supports for peptide synthesis. Anal Biochem 202: 210-214 (1992)

13. Park H-R, Tomida A, Sato S, Tsukumo Y, Yun J, Yamori T, Hayakawa Y, Tsuruo T, Shin-ya K. Blockade of survival response to glucose deprivation for selective killing of tumor cells. J Natl Can Inst 96: 1300-1330 (2004)

14. Ueda J, Hashimoto J, Nagai A, Nakashima T, Komaki H, Anzai K, Harayama S, Doi T, Takahashi T, Nagasawa K, Natsume T, Takagi M, Shin-ya K. New aureothin derivative, alloaureothin, from Streptomyces sp. MM23. J Antibiot 60: 321-324 (2007)

15. Choo S-J, Park H-R, Ryoo I-J, Kim J-P, Yun B-S, Kim C-J, Shin-ya K, Yoo I-D. Deoxyverrucosidin, a novel GRP78/BiP down-regulator, produced by Penicillium sp. J Antibiot 58: 210-213 (2005)

16. Park H-R, Ryoo I-J, Choo S-J, Hwang J-H, Kim J-Y, Cha MR, Shin-ya K, Yoo I-D. Glucose-deprived HT-29 human colon carcinoma cells are sensitive to verrucosidin as a GRP78 down-regulator. Toxicology 229: 253-261 (2007)

17. Yoshida T, Mori K, Hatano T, Okumura T, Uehara I, Komagoe K, Fujita Y, Okuda T. Studies on inhibition mechanism of autoxidation by tannins and flavonoids. V. Radical-scavenging effects of tannins and related polyphenols on 1,1-diphenyl-2-picrylhydrazyl radical. Chem Pharm Bull 37: 1919-1921 (1989) 